\title{
The Impact of Structured Input and Consciousness Raising Tasks on the Acquisition of Implicit and Explicit Knowledge of EFL Learners
}

\author{
Forouzan Zereshki ${ }^{1} \&$ Ghafour Rezaie ${ }^{1}$ \\ ${ }^{1}$ Department of English, Faculty of Humanities, Garmsar Branch, Islamic Azad University, Semnan, Iran \\ Correspondence: Forouzan Zereshki, Department of English, Faculty of Humanities, Garmsar Branch, Islamic \\ Azad University, Semnan, Iran. E-mail: forouzan.zereshki@chmail.ir
}

\author{
Received: November 23, 2017 Accepted: December 23, 2017 Online Published: February 4, 2018 \\ doi:10.5539/ijel.v8n3p55 URL: http://doi.org/10.5539/ijel.v8n3p55
}

\begin{abstract}
During the past decades, the distinction between implicit and explicit knowledge and how they could be developed through instruction have always been controversial issues for cognitive psychologists and second language acquisition (SLA) researchers. The present study was aimed at investigating the effects of two different input-based tasks (Structured Input and Consciousness Raising) on the acquisition of implicit and explicit knowledge of English active causative structure by EFL learners. Seventy three female English language learners participated in this study. Participants were divided into two experimental groups, one was provided with structured input activities and the other with consciousness raising activities. The participants' implicit and explicit knowledge of the target structure was assessed through Timed Grammaticality Judgment and Untimed Grammaticality Judgment respectively before and after the treatment. The results of Paired and Independent Samples t-test analyses revealed that both C-R tasks and SI tasks resulted in the acquisition of both implicit and explicit knowledge, with C-R having more significant impact on the explicit knowledge. The findings provided indirect positive support for the interface hypothesis.
\end{abstract}

Keywords: structured input tasks, consciousness raising task, implicit knowledge, explicit knowledge, EFL learners

\section{Introduction}

It is commonly agreed that explicit and implicit knowledge exist separately. Yet, there is noticeable dispute over the relationship between the two, particularly with respect to the role of instruction in the process of their acquisition (DeKeyser, 2003). A variety of tasks, including consciousness-raising and structured input tasks, have been used to develop these two types of knowledge in the learners. Ellis (2003) points out that consciousness raising (C-R) tasks differ from the focused tasks. Structure-based production tasks, enriched input tasks, and interpretation tasks are aimed at promoting implicit learning, whereas C-R tasks are designed to promote explicit learning. That is, they are used to develop awareness at the level of understanding rather than awareness at the level of noticing. Ellis (1997) defines C-R tasks as pedagogic activities where the learners are provided with L2 data and are required to perform some operation on them. The purpose of C-R tasks is to develop an explicit understanding of L2 data and the underlying rules. According to Mohamed (2004), C- R tasks, both deductive and inductive, offer an effective means of teaching grammar. On the other hand, Ellis (2008) states structured input (SI) tasks are a type of processing instruction whose aim is to develop implicit knowledge. Generally, there are two kinds of structured input activities: (a) referential SI, in which the learner I pushed to attend to or even rely on form or structure to get meaning; (b) affective SI, which allows the learner to express an opinion or a belief and be engaged in processing information about the real world, but not necessarily to get meaning from the target feature (Wong, 2004).

\subsection{Review of Literature}

Some important terms such as task, task based language teaching, structured input and consciousness raising tasks, implicit and explicit knowledge, and other technical terms are discussed to elaborate the whole notions which are examined in this study. Over the last three decades, all around the world, the focus of second language acquisition (SLA) researchers, curriculum developer, educationalists, teacher trainers and language teachers mainly has been devoted to task- based language teaching (TBLT) (Van den Branden, 2006; Lardiere, 2017; Long, 2017 ). Long (1985) and Norris et al. (2000) pointed out that the process of TBLT has been considered as 
a "top- down" process, in which the term was coined and then the concept was grown by SLA researchers and language educators in reaction to empirical account of teacher- dominated form- oriented second language classroom practice. Theoretically, TBLT was considered as a communicative language teaching, particularly a strong form (Ellis, 2012). Howat (1984) clarified this form in case of "using English to learn it". It seems that Howat (1984) has represented this version on the grounds that language is learned better through communicating (Ellis, 2012). The strong version of TBLT struggles to create opportunities for communication in the classroom. In a number of various approaches, including Krashen \& Terrell's (1983) Natural Approach, content- based language teaching and TBLT, this strong version is obviously seen (Ellis, 2012). Basically, the exact history of TBLT comes from 1980s, particularly from Prabhu's Communicational Language Teaching Project (Prabhu, 1987). According to Ellis (2003), a number of major publications would see it as ways of selecting tasks that would be highly beneficial for language learning, ways of designing a task- based syllabus, or ways of carrying out task-based language test (Norris, Brown, \& Hudson, 2000). Robinson (1997) declared that in the 2000s lots of books devoted to TBLT, and also in the first decade of the twentieth century these sort of books described practical TBLT lessons and. However, some authors like R. Following Van den Branden, Bygate, \& Norris (2009), TBLT is an approach that encompasses three fundamental dimensions of language education including; holistic learning, learner- driven, and communication-based instruction. It is completely different from traditional approaches (such as present- practice- produce- PPP) which are constructed from discrete learning, teacher- centered, and form- focused instruction. Long (1985), in their influential writings, supported an approach which provided students with functional tasks that required them to focus on primarily meaning and use language for real life situation rather than linguistic purposes. Much of the research on TBLT is conducted in laboratory conditions or in controlled setting. According to Van den Branden (2006) tasks are vehicles to elicit language production, interaction, negotiation of meaning, processing of input and focus on form, all of which are believed to foster second language acquisition. Finally, it seems that TBLT is a vehicle to pass from approaches which mostly focused on linguistic features to more meaning based approaches.

\subsection{Statement of the Problem}

How implicit and explicit knowledge is acquired and stored in the mind has attracted the attention of many researchers in field of applied linguistic (Dekeyser, 1998). It is generally argued that more explicit instructional activities lead to the development of explicit knowledge, whereas more implicit activities may result in the acquisition of implicit knowledge. In line with the discussion presented in the literature, this study attempted to investigate the impacts of explicit and implicit instructional activities on the acquisition of explicit and implicit knowledge. It was concerned with the problem of whether each of the two instructions of the SI (i.e., implicit FFI) and C-R (i.e., explicit FFI) tasks resulted in more implicit grammatical knowledge and/or explicit grammatical knowledge (Bataineh et al., 2017).

\subsection{Significance of the Study}

The present study was an endeavor to expand the previous studies by investigating whether C-R tasks and SI tasks significantly affect the development of either explicit or implicit grammatical knowledge. Although Ellis (2003) maintains that C-R tasks mostly influence explicit knowledge, the findings are not conclusive. While the results of the previous VanPatten's studies (1996) and Dekeyser (1998) confirmed the significant effect of SI on promoting learners' implicit grammatical knowledge, Nassaji \& Fotos' (2004) study is not in line with the result of this null hypothesis. They asserted that the difference between SI and C-R activities is not significant concerning their effects on acquisition of implicit knowledge. The results of the present study may provide more theoretical evidence ad to the effects of the C-R and SI tasks on the acquisition of implicit and explicit knowledge. The results may also provide additional positive support for the interface position on the status of implicit and explicit knowledge. Teachers and curriculum developers can also benefit from the results of the present study. The results can help them decide on the appropriate task types to promote implicit or explicit knowledge. Furthermore, the results may shed more light on the effectiveness of the C-R and SI tasks in the acquiring the second language in general.

\subsection{Objectives of the Study}

It was necessary to put forth clear cut research questions to tackle the problem of this research in a legitimate manner. The researcher intended to find the role of SI and C-R tasks in the process of acquiring second language knowledge. Generally, the specific questions motivating the research were as follows:

1) Does SI lead to significant gains in implicit knowledge?

2) Does C-R lead to significant gains in implicit knowledge? 
3) Does SI lead to significant gains in explicit knowledge?

4) Does C-R lead to significant gains in explicit knowledge?

5) Is there any significant difference between SI and C-R concerning their effects on the acquisition of implicit knowledge?

6) Is there any significant difference between SI and C-R concerning their effects on the acquisition of explicit knowledge?

\section{Methodology}

\subsection{Participants}

This study was conducted in Iranmehr Institute, Shahrak-e-Gharb branch. The participants were 73 EFL learners making up four intact classes. All the participants were female. They were divided into two experimental groups: C-R group and SI group. No control group was included in this study. The proficiency level of the participants was determined to be upper- intermediate, based on their performance on the Babel Placement Test. The age of participants ranged from 20 to 35 . At the time of data collection, all of the learners had completed language courses for more than 1 year at Iranmehr Institute and most of them tended to participate in IELTS or TOEFL exam. Two instructors cooperated to conduct the study, and both groups followed the same instructional goal and activities except the type of task used. The instruction process was done during 6 weeks ( 7 sessions). It seems essential to mention that teachers were clearly aware of what they were supposed to do in their classes due to the permanent contact with researcher and the debriefing sessions.

\subsection{Instruments}

The present research follows a pretest- treatment- posttest design. Before the pretest phase, the participants received the Babel Placement Test which was assigned in the first session of instruction in order to homogenize the learners of the research. In addition, a week before the first (and after the last) session of instruction, two tests containing the target structures were administered in following order: Timed Grammaticality Judgment Test (TGJT), Untimed Grammaticality Judgment Test (UGJT) (Kim \& Nam, 2017). The TGJT was intended to provide a measure of the learner's implicit knowledge, whereas the UGJT was designed to measures the learner's explicit knowledge. These instruments are broadly described below.

\subsection{Procedure}

The present study was an experimental conducted among upper intermediate English learners. Additionally, the design consisted of three phases: a pretest, an instructional treatment phase, a posttest phase. The classes were thus assigned to two experimental groups which received two types of input-based tasks: SI and C-R. At the beginning of the study in order to homogenize the groups, the Babel Placement Test was administered to the applicants and those who did not belong to the homogenized group were ignored during the data analysis phase. There were 4 classes that were assigned into two experimental groups $(n=39, n=34)$. Each group received one of the input- based tasks (either C-R or SI). Prior to the treatment, the pretest phase was conducted totally within 45 minutes. At first, 3.5 minutes was devoted to TGJT and then UGJT was administered. In this phase learners were asked to read 24 active causative sentences in each of them and decide on their grammaticality. This phase was aimed at determining the familiarity of the participants with the target structures at the outset of the study. In the next phase, treatment was provided for each group. Participants were exposed to target grammatical structure through 32 examples in 4 sessions. In other words, in each session 8 examples were given to the learners. The examples were equally divided to include both active causative constructions with have and get. Each treatment session lasted about 30 minutes. During four consecutive sessions two experimental groups received the same type of instructional treatment, which consisted of only one type of input- based tasks. These tasks followed the same scenario. In each session, one of the experimental groups received SI tasks (referential type) and the other experimental group received C-R tasks (deductive type). All of these tasks consisted of 8 active causative sentences which were required to be completed following the instructions given. Finally, a week after the fourth sessions of the treatment, the two types of measurement tests (i.e., TGJT and UGJT) for implicit and explicit knowledge were administered again as the posttest. Both tests were completed in a single session (first TGJT and then UGJT) that lasted approximately 45 minutes. The purpose of these posttests was to find out whether these tasks (SI and C-R) significantly differed in their effects on the acquisition of implicit and explicit knowledge of the target structures. Teachers in this study were observed by the researcher to make sure that they were following the procedure appropriately. 


\subsection{Data Analysis}

In order to test the research hypotheses proposed this phase of the experimental study involved the use of statistical analysis. First, the collected data were entered into SPSS software and then, depending on the nature of the problem, appropriate statistical procedures were used. It is necessary to mention that the data of this study were analyzed quantitatively. The mean scores of two types of tasks (SI and C-R) were compared at both pretest and posttest phase. For the null hypotheses 1,2,3 and 4, after the calculation of pretest and posttest implicit knowledge and explicit knowledge scores, four Paired Samples t-tests were run to measure the learner's improvement in implicit and explicit knowledge. This phase was intended to ascertain the relative effect of SI and C-R tasks on acquisition of implicit and explicit grammatical knowledge. Hypotheses 5 and 6 were tested through Independent Samples t-test analyses. Again, the posttest mean scores of the groups on both TGJT and UGJT were compared separately aimed at determining whether there was significant difference between the two types of tasks, SI and C-R, concerning their impacts on the learners' acquisition of implicit or explicit knowledge of grammar or not. Additionally the normality of the data was checked through Normal Q-Q Plots which seemed to be normal for all the groups.

\section{Results \& Discussion}

\subsection{Pretests Comparisons}

Prior to examining the hypotheses, the groups were compared at the pretest phase to see whether they were different from each other at the outset of the study or not. For this purpose, two Independent Samples t-tests were employed. The results, $\mathrm{t}(71)=0.058, \mathrm{P}=0.954$ and $\mathrm{t}(71)=1.428, \mathrm{P}=0.158$ showed that the groups did not significantly differ in terms of their mean scores (Table 1 and Table 2) on both explicit knowledge and implicit knowledge of the target grammatical structures. Therefore, if any difference is found at the posttest phase, it can be attributed to the treatment provided in each group.

Table 1. Descriptive statistics for pretests

\begin{tabular}{llllll}
\hline & Group & N & Mean & Std. Deviation & Std. Error Mean \\
\hline \multirow{2}{*}{ TGJpre } & Structured Input & 39 & 10.3077 & 3.30990 & .53001 \\
& Consciousness Raising & 34 & 10.3529 & 3.32012 & .56940 \\
\hline \multirow{2}{*}{ UGJpre } & Structured Input & 39 & 12.0000 & 2.41704 & .38704 \\
& Consciousness Raising & 34 & 11.1765 & 2.50419 & .42946 \\
\hline
\end{tabular}

Table 2. Independent samples t-test results for pretests

\begin{tabular}{|c|c|c|c|c|c|c|c|c|}
\hline & & \multicolumn{7}{|c|}{$\begin{array}{l}\text { Levene's Test for Equality oft-test for Equality of Means } \\
\text { Variances }\end{array}$} \\
\hline & & $\mathrm{F}$ & Sig. & $\mathrm{t}$ & $\mathrm{df}$ & $\begin{array}{l}\text { Sig. } \\
\text { (2-tailed) }\end{array}$ & $\begin{array}{l}\text { Mean } \\
\text { Difference }\end{array}$ & $\begin{array}{l}\text { Std. Error } \\
\text { Difference }\end{array}$ \\
\hline TGJpre & $\begin{array}{l}\text { Equal variances assumed } \\
\text { Equal variances not } \\
\text { assumed }\end{array}$ & .001 & .969 & $\begin{array}{l}-.058 \\
-.058\end{array}$ & $\begin{array}{l}71 \\
69.590\end{array}$ & $\begin{array}{l}.954 \\
.954\end{array}$ & $\begin{array}{l}-.04525 \\
-.04525\end{array}$ & $\begin{array}{l}.77773 \\
.77789\end{array}$ \\
\hline UGJpre & $\begin{array}{l}\text { Equal variances assumed } \\
\text { Equal variances not } \\
\text { assumed }\end{array}$ & .010 & .920 & $\begin{array}{l}1.428 \\
1.424\end{array}$ & $\begin{array}{l}71 \\
68.902\end{array}$ & $\begin{array}{l}.158 \\
.159\end{array}$ & $\begin{array}{l}.82353 \\
.82353\end{array}$ & $\begin{array}{l}.57671 \\
.57813\end{array}$ \\
\hline
\end{tabular}

\subsection{Testing Null Hypothesis I and Discussion}

The first null hypothesis was aimed at investigating whether SI led to any significant gain in implicit knowledge:

- SI does not lead to significant gains in implicit knowledge.

In order to test Hypothesis I, descriptive statistics along with paired samples t-test were used. As Table 3 indicates, the mean score for the SI group on the TGJT (implicit knowledge) has improved from pretest (M = $10.31)$ to posttest $(\mathrm{M}=14.21)$. This suggests that $\mathrm{SI}$ activities had positive effect on gaining implicit knowledge. 
Table 3. Descriptive statistics for structured input group in relation to TGJT

\begin{tabular}{llllll}
\hline & & Mean & N & Std. Deviation & Std. Error Mean \\
\hline Pair 1 & SIpreTGJ & 10.31 & 39 & 3.310 & .530 \\
& SIpostTGJ & 14.21 & 39 & 4.747 & .760 \\
\hline
\end{tabular}

A paired samples t-test statistics was used to examine whether the gains on the implicit knowledge test was statistically significant or not. The results, $\mathrm{t}(38)=24.59, \mathrm{P}=0.00$, indicated that, as presented in Table 4 , the difference between the pretest and posttest is statistically significant. Therefore, the null hypothesis is rejected.

Table 4. Paired samples t-test results for structured input in relation to TGJT

\begin{tabular}{|c|c|c|c|c|c|c|c|c|c|}
\hline \multicolumn{10}{|c|}{ Paired Samples Test } \\
\hline & & \multicolumn{8}{|c|}{ Paired Differences } \\
\hline & & \multirow[t]{2}{*}{ Mean } & \multirow[t]{2}{*}{ Std. Deviation } & \multirow[t]{2}{*}{ Std. Error Mean } & \multicolumn{5}{|c|}{$\begin{array}{l}95 \% \text { Confidence Interval } \\
\text { of the Difference }\end{array}$} \\
\hline & & & & & Lower & Upper & $\mathrm{t}$ & df & Sig. (2-tailed) \\
\hline Pair 1 & $\begin{array}{l}\text { SIpreTGJ } \\
\text { SIpostTGJ }\end{array}$ & -3.897 & 5.300 & .849 & -5.616 & -2.179 & -4.592 & 38 & .000 \\
\hline
\end{tabular}

Based on the information depicted in Tables 3 and 4, SI considered as an implicit FFI, led to significant gain in implicit knowledge. The results are compatible with the results of previous studies conducted by VanPatten (1996), Dekeyser (1998), Robinson (1997), and Ellis (2012). In these studies, SI activities were found to have significantly positive effects on learners' acquisition of implicit knowledge.

\subsection{Testing Null Hypothesis II and Discussion}

The purpose of null hypothesis II was to probe if C-R led to any significant gain in implicit knowledge:

- $\quad$ C-R does not lead to significant gains in implicit knowledge.

Table 5. Descriptive statistics for consciousness raising group in relation to TGJT

\begin{tabular}{llllll}
\hline & & Mean & $\mathbf{N}$ & Std. Deviation & Std. Error Mean \\
\hline Pair 1 & CRpreTGJ & 10.35 & 34 & 3.320 & .569 \\
\cline { 2 - 6 } & CRpostTGJ & 21.35 & 34 & 4.779 & .820 \\
\hline
\end{tabular}

In order to test hypothesis II, the researcher used descriptive statistics along with paired samples t-test. As it can be seen in Table 5, the mean score for the C-R group on the TGJT (implicit knowledge) has raised from pretest $(\mathrm{M}=10.35)$ to posttest $(\mathrm{M}=21.35)$. This recommends that $\mathrm{C}-\mathrm{R}$ activities have considerable impact on acquiring implicit knowledge.

Table 6. Paired samples t-test results for consciousness raising in relation to TGJT

\begin{tabular}{|c|c|c|c|c|c|c|c|c|c|}
\hline & & \multicolumn{8}{|c|}{ Paired Differences } \\
\hline & & \multirow[t]{2}{*}{ Mean } & \multirow[t]{2}{*}{ Std. Deviation } & \multirow[t]{2}{*}{ Std. Error Mean } & \multicolumn{5}{|c|}{$\begin{array}{l}95 \% \text { Confidence Interval } \\
\text { of the Difference }\end{array}$} \\
\hline & & & & & Lower & Upper & $\mathrm{t}$ & df & Sig. (2-tailed) \\
\hline Pair 1 & $\begin{array}{l}\text { SIpreTGJ } \\
\text { SIpostTGJ }\end{array}$ & -11.000 & 6.453 & 1.107 & -13.251 & -8.749 & -9.940 & 33 & .000 \\
\hline
\end{tabular}

It was, however, essential to examine whether the gain on the implicit knowledge was statistically significant or not. Therefore, a paired samples t-test statistics was used. The results, presented in Table 6, t (33) $=9.94, \mathrm{P}=$ 0.00 , demonstrated that the difference between the pretest and posttest is statistically significant. The null hypothesis II, therefore, is rejected at the $95 \%$ of confidence level. The results for null hypothesis II are not in line with previous studies provided by Ellis $(2003 ; 2009$; \& 2012) who maintained that C-R tasks primarily influence explicit knowledge. However, the findings here can provide some kind of positive support of interface hypothesis. It is possible that learners developed explicit knowledge which was then converted to implicit 
knowledge.

\subsection{Testing Null Hypothesis III and Discussion}

The third null hypothesis was intended to explore whether SI caused to any significant gain in explicit knowledge:

- SI does not lead to significant gains in explicit knowledge.

To test hypothesis III, the researcher made a comparison between the results of pretest and posttest scores on the UGJT (explicit knowledge). To perform this comparison, descriptive statistics and paired samples t-test were used together.

Table 7. Descriptive statistics for structured input group in relation to UGJT

\begin{tabular}{|c|c|c|c|c|c|}
\hline & & Mean & $\mathbf{N}$ & Std. Deviation & Std. Error Mean \\
\hline \multirow[t]{2}{*}{ Pair 1} & SIpreUGJ & 12.00 & 39 & 2.417 & .387 \\
\hline & SIpostUGJ & 14.31 & 39 & 5.110 & .818 \\
\hline
\end{tabular}

As Table 7 elaborates, the mean score for the SI group on the UGJT (explicit knowledge) in posttest $(\mathrm{M}=14.31)$ was higher than the mean score for pretest $(\mathrm{M}=12.00)$. This proposes that $\mathrm{SI}$ activities have positive impact on acquiring explicit knowledge.

Table 8. Paired samples t-test results for structured input in relation to UGJT

\begin{tabular}{|c|c|c|c|c|c|c|c|c|c|}
\hline & & \multicolumn{8}{|c|}{ Paired Differences } \\
\hline & & \multirow[t]{2}{*}{ Mean } & \multirow[t]{2}{*}{ Std. Deviation } & \multirow[t]{2}{*}{ Std. Error Mean } & \multicolumn{5}{|c|}{$\begin{array}{l}95 \% \text { Confidence Interval } \\
\text { of the Difference }\end{array}$} \\
\hline & & & & & Lower & Upper & $\mathrm{t}$ & df & Sig. (2-tailed) \\
\hline Pair 1 & $\begin{array}{l}\text { SIpreUGJ } \\
\text { SIpostUGJ }\end{array}$ & -2.308 & 4.996 & .800 & -3.927 & -.688 & -2.885 & 38 & .006 \\
\hline
\end{tabular}

In order to evaluate the statistical significance between the gains on the explicit knowledge, a paired sample t-test analysis was used. Table 8 illustrated the results between pretest and posttest UGJT (explicit knowledge). As presented in Table 8, t (38) $=2.88, \mathrm{P}=0.00$, the mean difference between the pretest and posttest is statistically significant. It means that our treatment is significantly affective. As a result, the null hypothesis III is rejected. According to Dekeyser \& Sokalski (1996) it can be concluded that SI tasks, as an implicit instruction, may provide a considerable improvement on gaining explicit knowledge. However, it should be mentioned that the researcher did not find any previous studies which held the same position with this hypothesis. The results here also may indirectly provide evidence for interface position, that is, learners might be able to develop explicit knowledge from the implicit knowledge they have gained.

\subsection{Testing Null Hypothesis IV and Discussion}

The null hypothesis IV was aimed at investigating whether C-R led to any significant gain in explicit knowledge:

- $\quad$ C-R does not lead to significant gains in explicit knowledge.

For the purpose of testing hypothesis IV, descriptive statistics along with paired samples t-test were used.

Table 9. Descriptive statistics for consciousness raising group in relation to UGJT

\begin{tabular}{|c|c|c|c|c|c|}
\hline & & Mean & $\mathbf{N}$ & Std. Deviation & Std. Error Mean \\
\hline \multirow[t]{2}{*}{ Pair 1} & CRpreUGJ & 11.18 & 34 & 2.504 & .429 \\
\hline & CRpostUGJ & 22.94 & 34 & 2.849 & .489 \\
\hline
\end{tabular}

Table 9 depicts that the mean score obtained by the C-R group on the UGJT (explicit knowledge) has improved from pretest $(M=11.18)$ to posttest $(M=22.94)$. The result indicates that $C-R$ activities have noticeably positive effect on learners' acquisition of explicit knowledge. 
Table 10. Paired samples t-test results for consciousness raising in relation to UGJT

\begin{tabular}{|c|c|c|c|c|c|c|c|c|c|}
\hline & & \multicolumn{8}{|c|}{ Paired Differences } \\
\hline & & \multirow[t]{2}{*}{ Mean } & \multirow[t]{2}{*}{ Std. Deviation } & \multirow[t]{2}{*}{ Std. Error Mean } & \multicolumn{5}{|c|}{$\begin{array}{l}\text { 95\% Confidence Interval } \\
\text { of the Difference }\end{array}$} \\
\hline & & & & & Lower & Upper & $\mathrm{t}$ & df & Sig. (2-tailed) \\
\hline Pair 1 & $\begin{array}{l}\text { CRpreUGJ } \\
\text { CRpostUGJ }\end{array}$ & -11.765 & 4.164 & .714 & -13.218 & -10.312 & -16.475 & 33 & .000 \\
\hline
\end{tabular}

On the next step, the researcher used a paired sample t-test statistics to analyze whether the results on the explicit knowledge test (UGJT) was statistically significant or not. The gains, $\mathrm{t}(33)=16.47, \mathrm{P}=0.00$, show that, as presented in Table 10, the difference between the pretest and posttest is statistically significant. The null hypothesis IV is, as a result, rejected. To put in a nutshell, we can conclude that C-R, which considered mainly as an explicit instruction in teaching grammar, cater explicit knowledge. Previous studies conducted by Mohamed (2004), Ellis (1997; 2003; \& 2010), Dekeyser (2003), and Robinson (1997) reported the same results related to this hypothesis. Therefore, the results concerning this hypothesis are highly compatible with the results of previous studies.

\subsection{Testing Null Hypothesis V and Discussion}

The purpose of the fifth hypothesis was to investigate whether significant difference is seen between SI and C-R tasks regarding their influence on acquisition of implicit knowledge:

- There is no significant difference between SI and C-R concerning their effects on acquisition of implicit knowledge.

In order to examine this hypothesis, the researcher used Descriptive Statistics along with Independent Sample t-test analysis.

Table 11. Descriptive statistics for TGJT at posttest

\begin{tabular}{llllll}
\hline & Group & N & Mean & Std. Deviation & Std. Error Mean \\
\hline TGJpost & Structured Input & 39 & 14.21 & 4.747 & .760 \\
& Consciousness Raising & 34 & 21.35 & 4.779 & .820 \\
\hline
\end{tabular}

Reading the mean column in Table 11 indicates that the mean score for the $\mathrm{C}-\mathrm{R}$ group $(\mathrm{M}=21.35)$ is higher than that of the SI group $(\mathrm{M}=14.21)$. This suggests that $\mathrm{C}-\mathrm{R}$ activities are more effective than the SI activities in promoting learners' implicit knowledge of grammar.

Table 12. Independent samples t-test results for TGJT at posttest

\begin{tabular}{|c|c|c|c|c|c|c|c|c|c|c|}
\hline & & \multicolumn{2}{|c|}{$\begin{array}{l}\text { Levene's Test } \\
\text { for Equality of } \\
\text { Variances }\end{array}$} & \multicolumn{7}{|c|}{ t-test for Equality of Means } \\
\hline & & \multirow[t]{2}{*}{$\mathrm{F}$} & \multirow[t]{2}{*}{ Sig. } & \multirow[t]{2}{*}{$\mathrm{t}$} & \multirow[t]{2}{*}{ df } & \multirow[t]{2}{*}{$\begin{array}{l}\text { Sig. } \\
\text { (2-tailed) }\end{array}$} & \multirow[t]{2}{*}{$\begin{array}{l}\text { Mean } \\
\text { Difference }\end{array}$} & \multirow[t]{2}{*}{$\begin{array}{l}\text { Std. Error } \\
\text { Difference }\end{array}$} & \multicolumn{2}{|c|}{$\begin{array}{l}95 \% \text { Confidence Interval } \\
\text { of the Difference }\end{array}$} \\
\hline & & & & & & & & & Lower & Upper \\
\hline \multirow[t]{2}{*}{ TGJpost } & $\begin{array}{l}\text { Equal variances } \\
\text { assumed }\end{array}$ & .696 & .407 & -6.397 & 71 & .000 & -7.148 & 1.117 & -9.376 & -4.920 \\
\hline & $\begin{array}{l}\text { Equal variances not } \\
\text { assumed }\end{array}$ & & & -6.394 & 69.519 & .000 & -7.148 & 1.118 & -9.378 & -4.918 \\
\hline
\end{tabular}

An Independent Samples t-test was run to examine if the difference between the two mean scores is statistically significant. As it can be seen from Table 12, the results from the t-test analysis, $\mathrm{t}(71)=6.39, \mathrm{P}=0.00$, showed that the two groups significantly differed from each other in terms of their posttest mean scores. As a result, the null hypothesis $\mathrm{V}$ is rejected. Finally, based on the results of previous studies, it is not easy to reach firm conclusion. While the results of the previous VanPatten's studies and Dekeyser \& Sokalski (1996) confirmed the significant effect of SI on promoting learners' implicit grammatical knowledge, Nassaji \& Fotos' (2004) study is not in line with the result of this null hypothesis. They asserted that the difference between SI and C-R activities 
is not significant concerning their effects on acquisition of implicit knowledge. As a result, the findings support the idea that both SI activities and C-R activities might lead to the development of implicit knowledge, as claimed by Nassaji \& Fotos (2004).

\subsection{Testing Null Hypothesis VI and Discussion}

The sixth and the last hypothesis was aimed at exploring if significant difference exists between SI and C-R activities relating their impact on learners' acquisition of explicit knowledge:

- There is no significant difference between SI and C-R concerning their effects on acquisition of explicit knowledge.

For the purpose of testing this hypothesis descriptive statistics along with Independent Sample t-test analysis were used.

Table 13. Descriptive statistics for UGJT at posttest

\begin{tabular}{llllll}
\hline & Group & N & Mean & Std. Deviation & Std. Error Mean \\
\hline \multirow{2}{*}{ UGJpost } & Structured Input & 39 & 14.31 & 5.110 & .818 \\
& Consciousness Raising & 34 & 22.94 & 2.849 & .489 \\
\hline
\end{tabular}

Comparing the mean column in Table 13 illustrates that the mean score for $C-R$ group $(M=22.94)$ is higher than that of the SI group $(\mathrm{M}=14.31)$. This obvious difference suggests that $\mathrm{C}-\mathrm{R}$ activities possess more effect than the SI activities on increasing learners' explicit knowledge of grammar. In order to examine whether the difference between the two mean scores is statistically significant, the researcher used an independent samples $\mathrm{t}$-test. The results from the t-test analysis, $\mathrm{t}(71)=8.73, \mathrm{P}=0.00$, indicated that, as presented in Table14, the two groups significantly differed from each other in case of their posttest mean scores. Therefore, the null hypothesis VI is rejected.

Table 14. Independent samples t-test results for UGJT at posttest

\begin{tabular}{|c|c|c|c|c|c|c|c|c|c|c|}
\hline & & \multicolumn{2}{|c|}{$\begin{array}{l}\text { Levene's Test for } \\
\text { Equality of } \\
\text { Variances }\end{array}$} & t-test f & or Equal & ity of Mean & & & & \\
\hline & & \multirow[t]{2}{*}{$\mathrm{F}$} & \multirow[t]{2}{*}{ Sig. } & \multirow[t]{2}{*}{$\mathrm{t}$} & \multirow[t]{2}{*}{$\mathrm{df}$} & \multirow[t]{2}{*}{$\begin{array}{l}\text { Sig. } \\
\text { (2-tailed) }\end{array}$} & \multirow[t]{2}{*}{$\begin{array}{l}\text { Mean } \\
\text { Difference }\end{array}$} & \multirow[t]{2}{*}{$\begin{array}{l}\text { Std. Error } \\
\text { Difference }\end{array}$} & \multicolumn{2}{|c|}{$\begin{array}{l}95 \% \text { Confidence } \\
\text { Interval of the } \\
\text { Difference }\end{array}$} \\
\hline & & & & & & & & & Lower & Upper \\
\hline \multirow[t]{2}{*}{ UGJpost } & $\begin{array}{l}\text { Equal variances } \\
\text { assumed }\end{array}$ & 13.194 & .001 & -8.734 & 71 & .000 & -8.633 & .989 & -10.605 & -6.662 \\
\hline & $\begin{array}{l}\text { Equal variances not } \\
\text { assumed }\end{array}$ & & & -9.059 & 61.000 & .000 & -8.633 & .953 & -10.539 & -6.728 \\
\hline
\end{tabular}

In a nutshell, recent studies particularly conducted by Smith (1981) and his followers Ellis $(1993 ; 2003 ; \& 2008$, 2012); Dekeyser (2003), Nassaji \& Fotos $(2004$; 2011) declared that C-R activities, which are primarily defined as explicit instruction, are more effective than SI tasks in improving the explicit grammatical knowledge. According to the previous research, it can be concluded that there is significant difference between these two types of input- based tasks regarding their effects on the learners' acquisition of explicit knowledge.

\section{Conclusion}

Offering a new approach in teaching grammar which significantly affected the domain of acquisition in terms of implicit and explicit knowledge has always been full of challenges. The motivation of present study was devoted into finding significant difference between two form- focused instructions ( SI and C-R) concerning their effects on two types of second language knowledge (i.e., implicit and explicit). This study was conducted to compare the acquisition of implicit and explicit grammatical knowledge of EFL learners who received SI activities (experimental group A) and C-R activities (experimental group B) to learn active causatives sentences. For this study, 4 classes of 73 female language learners at Iranmehr Institute participated. Two different structural packets, Babel Placement test, pretest and posttest were administered. The pretest and posttest consisted of two phases: TGJT and UGJT. A week after the pretest, the learners in each group received the targeted structure, active 
causative sentences (with verbs have and get) for four 30- minute class periods. Then, they were administered the posttest after the treatments a week later. The pretest, posttest mean scores of learners was compared between groups through Paired Samples t-test. As a result of the present study, the following results were obtained:

- Based on implicit knowledge results, C-R activities are more effective than the SI activities in promoting learners' acquisition of implicit grammatical knowledge.

- According to explicit knowledge gains, significant difference exists between C-R and SI activities in raising the acquisition of explicit knowledge of grammar. The results of the group who received C-R tasks were higher than the one's for the SI.

- In terms of evaluating the effectiveness of two input-based tasks (C-R and SI) in acquiring the implicit and explicit knowledge, C-R activities carried out significant impact on the learners' acquisition of explicit knowledge compared to SI activities.

\section{References}

Bataineh, R. F., Al-Qeyam, F. R., \& Smadi, O. M. (2017). Does form-focused instruction really make a difference? Potential effectiveness in Jordanian EFL learners' linguistic and pragmatic knowledge acquisition. Asian-Pacific Journal of Second and Foreign Language Education, 2(1), 17. https://doi.org/10.1186/s40862-017-0040-0

DeKeyser, R. (1998). Beyond focus on form: Cognitive perspectives on learning and practicing second language grammar. In C. Doughty \& J. Williams (Eds.), Focus on form in classroom second language acquisition publication (pp. 422-463).

DeKeyser, R. (2003). Implicit and explicit learning. In C. Doughty \& M. Long (Eds.), Handbook of Second Language Acquisition (pp. 313-349). Malden, MA: Blackwell. https://doi.org/10.1002/9780470756492.ch11

DeKeyser, R. M., \& Sokalski, K. J. (1996). The differential role of comprehension and production practice. Language Learning, 46(4), 613-642. https://doi.org/10.1111/j.1467-1770.1996.tb01354.x

Ellis, R. (1997). SLA Research and Language Teaching. New York: Oxford University Press.

Ellis, R. (2003). Task-based language learning and teaching. New York: Oxford University Press.

Ellis, R. (2008). Explicit knowledge and second language learning and pedagogy. In Encyclopedia of language and education (pp. 1901-1911). New York: Springer US. https://doi.org/10.1007/978-0-387-30424-3_145

Ellis, R. (2012). Language teaching research and language pedagogy. New York: John Wiley \& Sons. https://doi.org/10.1002/9781118271643

Howatt, A. (1984). A history of English language teaching. Oxford, England: Oxford University Press.

Kim, J. E., \& Nam, H. (2017). Measures of implicit knowledge revisited: Processing modes, time pressure, and modality. Studies in Second Language Acquisition, 39(3), 431-457. https://doi.org/10.1017/S0272263115000510

Krashen, S. D., \& Terrell, T. D. (1983). The natural approach: Language acquisition in the classroom. The Alemany Press.

Lardiere, D. (2017). Ultimate attainment in second language acquisition: A case study. London, New York: Routledge.

Long, M. (1985). Input and second language acquisition theory. Input in second language acquisition, 377-393.

Long, M. H. (2017). Problems in second language acquisition. London, New York: Routledge.

Mohamed, N. (2004). Consciousness-raising tasks: A learner perspective. ELT Journal, 58(3), 228-237. https://doi.org/10.1093/elt/58.3.228

Nassaji, H., \& Fotos, S. (2004). Current developments in research on the teaching of grammar. Annual Review of Applied Linguistics, 24(2), 126-145. https://doi.org/10.1017/S0267190504000066

Nassaji, H., \& Fotos, S. S. (2011). Teaching grammar in second language classrooms: Integrating form-focused instruction in communicative context. London, New York: Routledge.

Norris, J. M., Brown, J. D., Hudson, T. D., \& Bonk, W. (2000). Assessing performance on complex L2 tasks: investigating raters, examinees and tasks. In 22nd Language Testing Research Colloquium, Vancouver, March. 
Prabhu, N. S. (1987). Second language pedagogy (Vol. 20). Oxford: Oxford University Press.

Robinson, P. (1997). Generalizability and automaticity of second language learning under implicit, incidental, enhanced, and instructed conditions. Studies in Second Language Acquisition, 19(2), 223-247. https://doi.org/10.1017/S0272263197002052

Smith, M. S. (1981). Consciousness-Raising and the Second Language Learner. Applied Linguistics, 2(2), 159-168. https://doi.org/10.1093/applin/2.2.159

Van Den Branden, K. (2006). Introduction: Task-based language teaching in a nutshell. Cambridge: Cambridge University press. https://doi.org/10.1017/CBO9780511667282.002

Van den Branden, K., Bygate, M., \& Norris, J. (2009). Task-based language teaching: A reader. Amsterdam: John Benjamins. https://doi.org/10.1075/tblt.1

VanPatten, B. (1996). Input processing and grammar instruction: Theory and research.

Wong, W. (2005). Input enhancement: From theory and research to the classroom. New York: McGraw-Hill.

\section{Copyrights}

Copyright for this article is retained by the author(s), with first publication rights granted to the journal.

This is an open-access article distributed under the terms and conditions of the Creative Commons Attribution license (http://creativecommons.org/licenses/by/4.0/). 